Bangladesh J. Bot. 38(1): 87-91, 2009 (June)

\title{
BACTERIAL LOAD AND CHEMICAL POLLUTION LEVEL OF THE RIVER BURIGANGA, DHAKA, BANGLADESH
}

\author{
Mihir Lal Saha*, Mahbubar Rahman Khan, Mohammad Ali \\ AND SIRAJUl HOQUE ${ }^{1}$ \\ Laboratory of Microbiology, Department of Botany, University of Dhaka, \\ Dhaka-1000, Bangladesh
}

Key words: Bacteria, Buriganga River, Enteric bacteria, Pollution, Bangladesh

\begin{abstract}
The River Buriganga is the life line of the Dhaka city and flanked in its southern side. The aerobic heterotrophic bacterial count of the River Buriganga was found to be in the range of $1.0 \times 10^{5}$ to $42.0 \times$ $10^{5} \mathrm{cfu} / \mathrm{ml}$ while enteric bacterial counts on SS agar and MacConkey agar were $0.1 \times 10^{4}$ to $39.0 \times 10^{4} \mathrm{cfu} / \mathrm{ml}$ and $0.3 \times 10^{3}$ to $3.5 \times 10^{4} \mathrm{cfu} / \mathrm{ml}$ samples, respectively. Out of 74 isolates, 5 Gram-positive (22\%) and 18 Gram-negative (78\%) bacteria were randomly selected for detailed study. Bacillus was the dominant among the Gram-positive bacteria. Eighteen Gram-negative enteric isolates belonged to the genera Enterobacter (E. amnigenus and E. intermedium (44\%), Alcaligenes (28\%), Salmonella (17\%), Escherichia (5.6\%) and Plesiomonas) (5.6\%). The $\mathrm{NO}_{3}^{-}-\mathrm{N}, \mathrm{NO}_{2}^{-}-\mathrm{N}$ and phosphorus concentrations were found to be below the safety level from pollution point of view. BOD and COD values along with the presence of different bacteria clearly indicated that the River Buriganga was polluted with the organic, chemical and bacterial pollutants.
\end{abstract}

\section{Introduction}

There has been growing concern about the need to protect the environment from the various forms of pollution caused by growing populations, industrialization, use of modern agricultural methods etc. (Hunt and Wilson 1986).

Microorganisms often play a major role in determining the extent of this pollution (Higgins and Burns 1975). Municipal waste water is a primary contributor of bacteria to the aquatic environment (Linton et al. 1974). The presence of faecal coliform is considered as presumptive evidence of faecal pollution (Mara 1978). Pathogenic bacteria that have been transmitted by water or waste water include, Salmonella, Campylobacter, Vibrio cholarae, Leptospira and Yersinia (Anonymous 1992). In Bangladesh, about $80 \%$ of all diseases are associated with waterborne diseases. About 300,000 children under five die of diarrhoeal diseases every year, of which one third of the deaths occurs in the city slums and squatter settlements (GOB-UNICEF 1991). Studies on the pollution aspects of this kind of water is very significant because these settlaments use this water for various domestic purposes (Geldreich 1996).

The River Buriganga is Dhaka's main outlet of sewage waste. In addition anthropogenic effects have seriously affected the physicochemical and biological conditions of the river. Considering above situation and facts, the present work was undertaken to determine aerobic heterotrophic and enteric bacteria to the context of biological pollution level along with the physico-chemical properties to reveal an overall status of pollution of the River Buriganga.

\section{Materials and Methods}

Sampling sites and collection of water samples: The water samples were collected from four sites (Br-1 to Br-4) of the River Buriganga, Dhaka, Bangladesh (Fig. 1). From each site, samples were collected from four points across the width of the river. Water samples were collected in plastic bottles sterilized with alcohol.

*Corresponding author: E-mail <sahaml@yahoo.com>. ${ }^{1}$ Department of Soil, Water and Environment, University of Dhaka, Dhaka-1000, Bangladesh. 
Bacteriological analysis: Nutrient agar (NA) medium was used for the enumeration and isolation of aerobic heterotrophic bacteria. MacConkey agar (Difco) and SS agar (Diagnostic Pasteur) media were used for the determination and isolation of enteric bacteria. The $\mathrm{pH}$ of the isolation media was adjusted to 7.2 before sterilization. Three different techniques, viz. serial dilution plate (Clesceri et al. 1998), spread plate (Sharp and Lyles 1969) and membrane filtration technique (Atlas et al. 1995) were used for the enumeration and isolation of bacteria. Inoculated bacterial plates were incubated at $37^{\circ} \mathrm{C}$ for 24 hour.

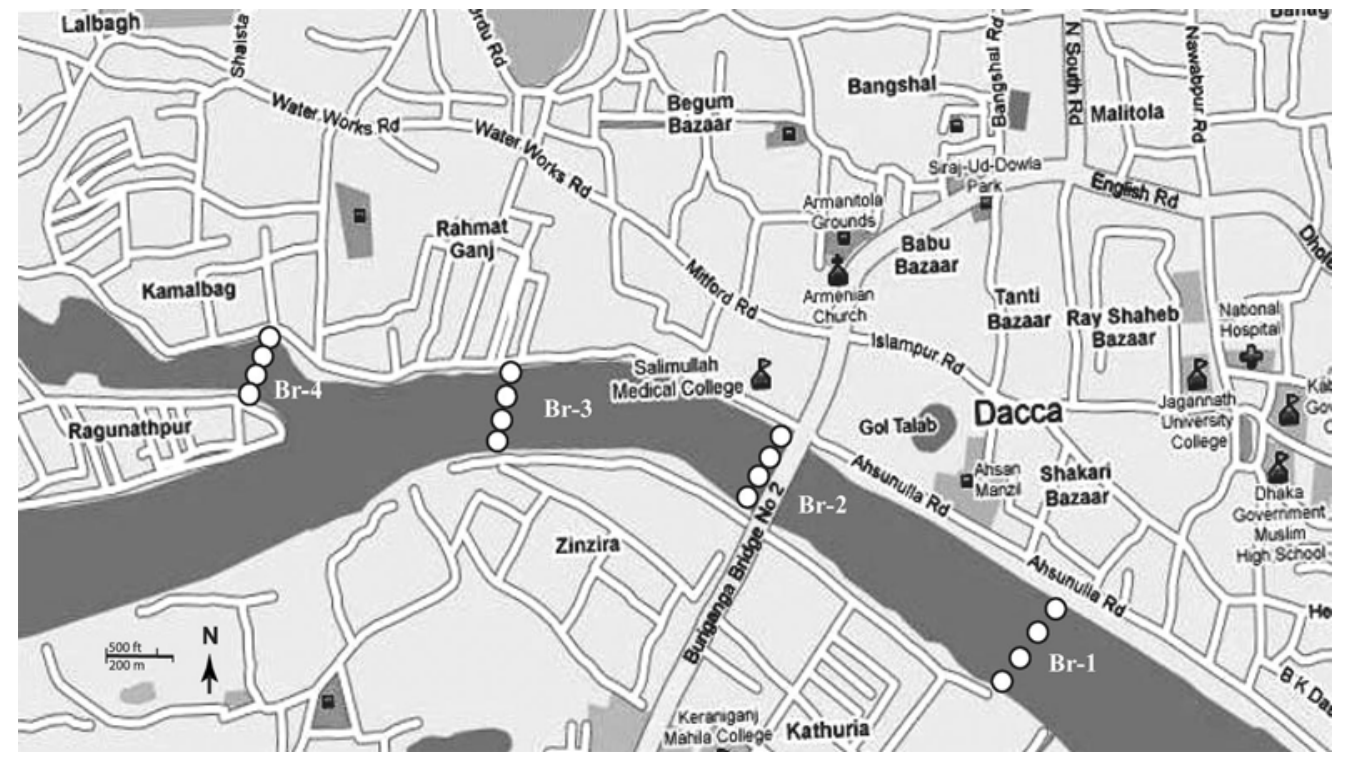

Fig. 1. Map showing different sampling sites of the River Buriganga, Dhaka, Bangladesh $(\mathrm{Br}-1=$ Sadar ghat, $\mathrm{Br}-2$ = Mitford ghat, Br-3 = Sowari ghat and $\mathrm{Br}-4=$ Shmashan ghat).

Bacterial colony countintg was made with the help of a digital colony counter (OSK 10086, DC-3, Japan). Discrete bacterial colonies were isolated immediately after counting. For provisional identification of bacteria important biochemical tests were carried out, viz. carbohydrate fermentation, arginine hydrolysis, catalase test, deep glucose agar test, tyrosine degradation, egg-yolk lecithinase test, casein hydrolysis, protease test, gelatin hydrolysis, starch hydrolysis, Kligler's iron agar (KIA) test, levan test, methyl red test, nitrate reduction test, oxidase test, indole production, phenylalanine deaminase test, citrate utilization, utilization of propionate, urease production test, Voges-Proskauer (VP) test, etc. Bergey's Manual for Systematic Bacteriology, Vol. 2 (Sneath et al. 1986) was followed for the identification of Grampositive aerobic heterotrophic bacterial isolates. On the other hand enteric bacteria were identified by using standard method following Manual for Laboratory Investigations of Acute Enteric Infections (WHO 1987) and Bergey's Manual of Systemetic Bacteriology, Vol. 1 (Krieg and Holt 1984).

Determination of physico-chemical properties: Temperature of water was measured at the time of water sampling with the help of a thermometer. The $\mathrm{pH}$ of collected water samples was measured in the laboratory by electronic $\mathrm{pH}$ meter (Jenway 3310, U.K.). For chemical analysis, samples were filtered (Whatman No. 42, England) to eliminate suspended solid particles. Nitritenitrogen present in water was determined by modified Griess-Ilosvay (Barnes and Folkard 1951, Bremner 1965) method. Nitrate-nitrogen present in water was determined colorimetrically (Joergensen and Brookes 1990). Soluble reactive phosphorus was determined by ascorbic acid 
blue method (Murphy and Riley 1962). Biological oxygen demand (BOD) was determined by BOD meter (Mettler-Todelo CH-8603 Schwerzenbanch, USA) while chemical oxygen demand (COD) was analysed by the method based on chemical oxidation of materials in the presence of catalyst by $\mathrm{Cr}_{2} \mathrm{O}_{7^{2-}}$ in $50 \% \mathrm{H}_{2} \mathrm{SO}_{4}$ as described by De (1999).

\section{Results and Discussion}

Bacterial count of the water samples of the River Buriganga revealed substantial number of aerobic heterotrophic bacteria (Table 1). The highest count was found in the station Shmashan ghat. Heterotrophic bacterial load in the rainy season was found to be higher than the winter. This might be due to wash out of the land surface to the river by rain water.

Table 1. Bacterial count (cfu/ml) of water samples of the River Buriganga.

\begin{tabular}{|c|c|c|c|c|c|c|}
\hline \multirow[b]{2}{*}{ Season } & \multirow[b]{2}{*}{$\begin{array}{l}\text { Sampling } \\
\text { sites }\end{array}$} & \multirow{2}{*}{$\begin{array}{c}\text { Aerobic } \\
\text { heterotrophic } \\
\text { bacteria on } \\
\text { nutrient agar }\end{array}$} & \multicolumn{2}{|c|}{ Enteric bacteria on } & \multirow{2}{*}{$\begin{array}{l}\text { Average } \\
\text { enteric } \\
\text { bacteria }\end{array}$} & \multirow{2}{*}{$\begin{array}{c}\text { Total } \\
\text { bacterial } \\
\text { load }\end{array}$} \\
\hline & & & $\begin{array}{c}\text { MacConkey } \\
\text { agar }\end{array}$ & $\begin{array}{l}\text { SS } \\
\text { agar }\end{array}$ & & \\
\hline \multirow{4}{*}{$\begin{array}{c}\text { Rainy } \\
\text { season } \\
\text { (July-Aug) }\end{array}$} & Sadar ghat & $5.0 \times 10^{5}$ & $3.5 \times 10^{4}$ & $3.5 \times 10^{4}$ & $3.5 \times 10^{4}$ & $2.67 \times 10^{5}$ \\
\hline & Mitford ghat & $6.0 \times 10^{5}$ & $0.8 \times 10^{4}$ & $0.5 \times 10^{4}$ & $0.7 \times 10^{4}$ & $3.35 \times 10^{5}$ \\
\hline & Sowari ghat & $6.1 \times 10^{5}$ & $0.3 \times 10^{4}$ & $0.1 \times 10^{4}$ & $0.2 \times 10^{4}$ & $3.06 \times 10^{5}$ \\
\hline & Shmashan ghat & $42.0 \times 10^{5}$ & $1.2 \times 10^{4}$ & $0.4 \times 10^{4}$ & $0.8 \times 10^{4}$ & $21.00 \times 10^{5}$ \\
\hline \multirow{4}{*}{$\begin{array}{c}\text { Winter } \\
\text { season } \\
\text { (Jan-Feb) }\end{array}$} & Sadar ghat & $1.4 \times 10^{5}$ & $2.7 \times 10^{4}$ & $1.3 \times 10^{4}$ & $2.0 \times 10^{4}$ & $0.80 \times 10^{5}$ \\
\hline & Mitford ghat & $3.1 \times 10^{5}$ & $1.4 \times 10^{4}$ & $1.5 \times 10^{4}$ & $1.5 \times 10^{4}$ & $1.63 \times 10^{5}$ \\
\hline & Sowari ghat & $1.0 \times 10^{5}$ & $1.1 \times 10^{4}$ & $3.5 \times 10^{4}$ & $2.3 \times 10^{4}$ & $0.62 \times 10^{5}$ \\
\hline & Shmashan ghat & $2.2 \times 10^{5}$ & $2.1 \times 10^{4}$ & $39 \times 10^{4}$ & $20.6 \times 10^{4}$ & $2.13 \times 10^{5}$ \\
\hline
\end{tabular}

Enteric bacterial count on MacConkey agar ranged between $0.3 \times 10^{4}$ and $3.5 \times 10^{4} \mathrm{cfu} / \mathrm{ml}$ and the highest count was found in the sample of Shmashan ghat. Average bacterial count on SS agar medium varied between $0.1 \times 10^{4}$ and $39.0 \times 10^{4} \mathrm{cfu} / \mathrm{ml}$ and the maximum count $\left(39.0 \times 10^{4}\right)$ was also observed in Shmashan ghat. The Shmashan ghat area was found to be highly polluted with enteric bacterial pollution. Interestingly the maximum count $\left(20.6 \times 10^{4} \mathrm{cfu} / \mathrm{ml}\right)$ of enteric bacteria was noticed during the winter season. During this study heterotrophic along with the enteric bacterial load ranged between $0.62 \times 10^{5}$ and $21.0 \times 10^{5} \mathrm{cfu} / \mathrm{ml}$. The results demonstrated that the River Buriganga is considerably polluted with bacterial population. Garnier et al. $(1991,1992)$ and Hasan et al. (2006) reported more or less similar results showing the load of heterotrophic and nitrifying bacteria in the river and sewage lagoon.

During this investigation, of the 74 isolates, 23 were randomly selected and purified for detailed study. Among these, 5 were Gram-positive and remaining 18 were Gram-negative. Among the Gram-positive, 4 isolates were rod, spore former and members of the genus Bacillus (B. fastidiosus and B. alvei) and the remaining one was the member of Planococcus. The result clearly indicated that among the Gram-positive bacteria, spore former Bacillus was the dominant genus.

Enteric bacteria were Gram-negative, short rod and non-spore former. Out of 18 Gramnegative enteric bacterial isolates, 8 (44\%) isolates belonged to the genus Enterobacter, 5 (28\%) to the genus Alcaligenes, $3(17 \%)$ to the genus Salmonella and the remaining two strains were Escherichia coli (5.6\%) and member of Plesiomonas (5.6\%) (Table. 2). Enterobacter was found to be the dominant group among the Gram-negative bacteria in the River Buriganga. 
The coliform group of bacteria in general and E. coli in particular, was found to be universal indicator of faecal contamination (Godfree et al. 1997). Presence of E. coli, thus clearly indicated faecal pollution of the River Buriganga.

Table 2. Provisional identification of the selected bacterial strains from different sites.

\begin{tabular}{|c|c|c|c|c|c|}
\hline Sites & $\begin{array}{l}\text { Strain } \\
\text { Nos. }\end{array}$ & $\begin{array}{l}\text { Identified } \\
\text { bacteria }\end{array}$ & Sites & $\begin{array}{l}\text { Strain } \\
\text { Nos. }\end{array}$ & $\begin{array}{l}\text { Identified } \\
\text { bacteria }\end{array}$ \\
\hline Br-1 & M-1 & Enterobacter sp. & $\mathrm{Br}-2$ & M-7 & Escherichia coli \\
\hline $\mathrm{Br}-1$ & M-2 & E. amnigenus & $\mathrm{Br}-2$ & M-8 & Salmonella sp. \\
\hline $\mathrm{Br}-1$ & N-1 & Plesiomonas sp. & $\mathrm{Br}-2$ & $\mathrm{~N}-2$ & Bacillus alvei \\
\hline $\mathrm{Br}-1$ & N-5 & Alcaligenes sp. & Br-2 & $\mathrm{N}-3$ & B. fastidiosus \\
\hline $\mathrm{Br}-1$ & N-6 & Alcaligenes sp. & $\mathrm{Br}-3$ & M-10 & Salmonella paratyphi \\
\hline $\mathrm{Br}-1$ & $\mathrm{~N}-7$ & Enterobacter amnigenus & $\mathrm{Br}-3$ & M-9 & Enterobacter amnigenus \\
\hline Br-1 & $\mathrm{N}-8$ & Planococcus & $\mathrm{Br}-3$ & S-3 & Alcaligenes sp. \\
\hline $\mathrm{Br}-1$ & N-9 & Bacillus fastidiosus & $\mathrm{Br}-3$ & S-4 & Salmonella paratyphi A \\
\hline $\mathrm{Br}-2$ & M-3 & B. fastidiosus & $\mathrm{Br}-4$ & M-11 & Enterobacter amnigenus \\
\hline $\mathrm{Br}-2$ & M-4 & Enterobacter sp. & Br-4 & $\mathrm{N}-4$ & Alcaligenes sp. \\
\hline $\mathrm{Br}-2$ & M-5 & E. amnigenus & $\mathrm{Br}-4$ & S-5 & Alcaligenes sp. \\
\hline $\mathrm{Br}-2$ & M-6 & E. intermedium & & & \\
\hline
\end{tabular}

$\mathrm{Br}-1$ = Sadar ghat, $\mathrm{Br}-2$ = Mitford ghat, $\mathrm{Br}-3$ = Sowari ghat and $\mathrm{Br}-4=$ Shmashan ghat .

Physicochemical properties of the water of the River Buriganga are given in Table 3. According to United State Public Health (USPH) standard, $5 \mathrm{mg} / \mathrm{l}$ and $4 \mathrm{mg} / \mathrm{l}$ value of BOD and COD, respectively indicate the quality for domestic and drinking water (De 1999). The normal range of BOD for good water quality is 5-6 mg/l and COD is 6-10 mg/l (Huq et al. 2005). Higher BOD and COD values indicated that water of the River Buriganga was considerably polluted with organic and chemical pollutants.

Table 3. Physico-chemical properties of the water samples of the River Buriganga.

\begin{tabular}{|c|c|c|c|c|c|c|c|c|}
\hline Season & $\begin{array}{l}\text { Sampling } \\
\text { sites }\end{array}$ & $\begin{array}{c}\text { Temp. } \\
\left({ }^{\circ} \mathrm{C}\right)\end{array}$ & $\mathrm{pH}$ & $\begin{array}{c}\text { BOD } \\
(\mathrm{mg} / \mathrm{l})\end{array}$ & $\begin{array}{c}\text { COD } \\
(\mathrm{mg} / \mathrm{l})\end{array}$ & $\begin{array}{c}\mathrm{P} \\
(\mathrm{mg} / \mathrm{l})\end{array}$ & $\begin{array}{c}\mathrm{NO}_{2}^{-}-\mathrm{N} \\
(\mathrm{mg} / \mathrm{l})\end{array}$ & $\begin{array}{c}\mathrm{NO}_{3}^{-}-\mathrm{N} \\
(\mathrm{mg} / \mathrm{l})\end{array}$ \\
\hline \multirow{4}{*}{$\begin{array}{c}\text { Rainy } \\
\text { season } \\
\text { (July-Aug) }\end{array}$} & Sadar ghat & 29.5 & 7.10 & & 54.9 & 0.21 & 0.30 & \multirow{4}{*}{ Trace } \\
\hline & Mitford ghat & 29.0 & 6.44 & Not & 289.5 & 0.09 & 0.35 & \\
\hline & Sowari ghat & 30.0 & 6.90 & Done & 192.1 & 0.09 & 0.03 & \\
\hline & Shmashan ghat & 31.0 & 6.25 & & 219.6 & 0.18 & 0.05 & \\
\hline \multirow{4}{*}{$\begin{array}{c}\text { Winter } \\
\text { season } \\
\text { (Jan-Feb) }\end{array}$} & Sadar ghat & 18.3 & 7.05 & 9.1 & 22.3 & 0.89 & 0.41 & \multirow{4}{*}{ Trace } \\
\hline & Mitford ghat & 18.5 & 7.14 & 15.1 & 24.0 & 0.72 & 0.56 & \\
\hline & Sowari ghat & 20.7 & 7.16 & 7.7 & 16.8 & 0.75 & 0.40 & \\
\hline & Shmashan ghat & 19.8 & 7.00 & 11.2 & 40.3 & 1.78 & 0.15 & \\
\hline
\end{tabular}

Natural level of nitrate-nitrogen in ground and surface water are usually below $0.2 \mathrm{mg} / \mathrm{l}$. Extensive epidemiological data support the current guideline values for $\mathrm{NO}_{3}{ }^{-} \mathrm{N}$ of $10 \mathrm{mg} / \mathrm{l}$ (WHO 1993). According to the United States Public Health (USPH), drinking water standards were $\mathrm{pH}$ 6.0 to $8.5, \mathrm{NO}_{2}<10$ and $\mathrm{NO}_{3}<10$ to $45 \mathrm{mg} / \mathrm{l}$ (De 1999). During the present study, major chemical contents like $\mathrm{NO}_{3}^{-}-\mathrm{N}, \mathrm{NO}_{2}^{-}-\mathrm{N}$ and phosphorus values were found to be low and below the safety level from the pollution point of view. 
The load of aerobic heterotrophic bacteria and the presence and abundance of Enterobacter, Alcaligenes, Salmonella, Escherichia, Plesiomonas, etc. in the water clearly showed significant level of microbial pollution of the river. On the basis of BOD and COD values, the River Buriganga water was polluted with organic and chemical pollutants. Well managed waste disposal system should be practiced to save the River Buriganga from the pollution.

\section{References}

Anonymous. 1992. Standard Methods for the Examination of Water and Wastewater. APHA/AWWA/ WPCF, Washington DC. pp. 756.

Atlas, R.M., A.E. Brown and L.C. Parks. 1995. Laboratory Manual Experimental Microbiology. Mosbyyearbook, Inc. St. Louis. Missouri. pp. 565.

Barnes, H. and A.R. Folkard. 1951. The determination of nitrites. Analyst (London). 76: 599-603.

Bremner, J.M. 1965. Inorganic forms of nitrogen. In: Methods of soil analysis, part-2. Agronomy, (C.A. Black et al. Eds.), Am. Soc. Agron., Inc., Madison, Wis. 9: 1179-1237.

Clesceri, L.S., A.E. Greenberg and A.D. Eaton. 1998. Standard methods for examination of water and wastewater. APHA. Washington DC. Chapter 9, pp. 140.

De, A.K. 1999. Environmental chemistry. New Age International Limited Publishers, New Delhi. pp. 364.

Garnier, J., P. Servais and G. Billen. 1991. Bacterioplankton in the Seine River: Impact of the Parisian urban effluents. Can. J. Microbiol. 38: 56-64.

Garnier, J., G. Billen and P. Servais. 1992. Physiological characteristics and ecological role of small and large sized bacteria in a polluted river (Seine River, France). Arch Hydrobiol Ergebn Limnol. 37: 83-94.

Geldreich, E.E. 1996. Pathogenic agents in freshwater resources. Hydrological processes 10: 315-333.

GOB-UNICEF. 1991. Rural water supply and sanitation program. 1992-1999, Dhaka.

Godfree, A.F., D. Kay and M.D. Wyer. 1997. Faecal streptococci as indicators of faecal contamination in water. J. Appl. Micribiol. Symp. Supplement 83: 110-119.

Hasan, M.M., M.K. Ahmed, F. Hafiz, A.M.I. Hussain, S. Parveen and S.R. Tinni. 2006. Load of heterotrophic and nitrifying bacteria in the sewage lagoon and the River Buriganga. Bangladesh J. Microbiol. 23(2): 93-97.

Higgins, I.J. and R.G. Burns. 1975. The Chemistry and Microbiology of Pollution. Academic Press, London.

Hunt, D.T.E. and A.L. Wilson. 1986. The chemical analysis of water. The Royal Society of Chemistry, Burlington House, London. pp. 683.

Hunter, P.R. 1993. The microbiology of bottled natural mineral waters. J. Appl. Bacteriol. 74: 345-352.

Huq, S.M.I. and M.D. Alam. 2005. A Handbook on analyses of Soil, Plant and Water. BACER-DU, University of Dhaka. pp. 246.

Joergensen, R.G. and Brookes. 1990. Ninhydrin reactive nitrogen measurements of microbial biomass in 0.5M K $\mathrm{M}_{2} \mathrm{SO} 4$ soil extracts. Soil Biol. Biochem. 22: 1023-1027.

Krieg, N.R. and J.G. Holt. 1984. Bergey’s Manual of Systematic Bacteriology (Vol. 1). The Williams and Wilkins Company, Baltimore. pp. 964.

Linton, K.B., M.H. Richmond, R. Bevau and W.A. Cillespie. 1974. Antibiotic resistance and R-factors in coliform bacilli isolated from hospital and domestic sewage, J. Medical Microbiol. 7: 91-103.

Mara, D. 1978. Sewage Treatment in Hot Climates. John Wiley and sons, New York. pp.168.

Murphy, J. and J.P. Riley. 1962. A modified single solution method for determination of phosphate in natural water. Anal. Chem. Acta. 27: 31-36.

Sharp, M.S. and S.T. Lyles. 1969. Laboratory instruction in biology of microorganisms. Saint Louis the C V Mosley Company, St. Louis. pp. 23-25.

Sneath, P.H.A., N.S. Mair, M.E. Sharpe and J.G. Holt. 1986. Bergey’s manual of systematic bacteriology. Vol. 2. Williams and Wilkins Co., Baltimore. pp. 965-1599.

WHO. 1987. Manual for laboratory investigations of acute enteric infections. CDD/83.3 Rev. 1. pp. 113.

WHO. 1993. Guidelines for drinking water quality. 2nd edn. Geneva. 1: 25-100. 